\title{
Epidemiologi, Stadium, dan Derajat Diferensiasi Kanker Kepala dan Leher
}

\author{
NELSIANI TO’BUNGAN ${ }^{1}$, SITI HAMIDATUL A’LIYAH², NASTITI WIJAYANTI ${ }^{3}$, \\ JAJAH FACHIROH ${ }^{4}$ \\ ${ }^{1}$ Fakultas Teknobiologi Universitas Atma Jaya Yogyakarta \\ Jln. Babarsari No. 44 Yogyakarta 55281 \\ email: nelsitobungan@gmail.com \\ ${ }^{2}$ Fakultas farmasi Program Studi farmasi STIKES Harapan Ibu Jambi \\ Jl. Tarmizi Kadir No. 71 Pakuan Baru jambi 36132 \\ email: sitihamidatula@gmail.com \\ ${ }^{3}$ Fakultas Biologi Universitas Gadjah Mada Yogyakarta \\ Jl. Teknika Selatan, Sekip Utara, Daerah Istimewa Yogyakarta 55281 \\ email: nastitiw@yahoo.com \\ ${ }^{4}$ Fakultas Kedokteran Universitas Gadjah Mada \\ Jl. Farmako Sekip Utara Yogyakarta 55281 \\ email: jfachiroh@gmail.com
}

\begin{abstract}
Head and neck cancer is one of the deadly types of cancer in Indonesia. The main cause of this cancer is the consumption of alcohol and cigarettes. Head and neck cancer attacks the lips, mouth, palate, pharynx and larynx. Studies about head and neck cancer have been carried out in western countries, while in Indonesia is still limited. Earlier studies in western countries expressed that head and neck cancer is more common in men than women. Purpose of research were to determine the epidemiology of head and neck cancer in Indonesia related to patient ratio of men and women and the correlation of stage and differentiation level of head and neck cancer. Data were obtained from the Rumah Sakit Kanker Dharmais-Pusat Kanker Nasional Jakarta and then analyzed descriptively. The data were analyzed came from 36 patients with head and neck cancer. The results showed, men with head and neck cancer as much as $52,77 \%$ and females $47,22 \%$. There were 16 cases with stage IV cancer, 9 with stage III, 8 with stage II and 2 with stage I. There were 6 cases of stage IV cancer with better differentiation, and there were 2 cases of stage II cancer with a poor differentiation. Head and neck cancer is more common in men than women. There was no correlation between the degree of differentiation-stage head and neck cancer. It was influenced by immunity of each person.
\end{abstract}

Keywords: differentiation level, epidemiology, head and neck cancer, stage

\section{PENDAHULUAN}

Kanker adalah salah satu penyakit yang mematikan. Kanker berasal dari pertumbuhan abnormal sel atau jaringan yang bersifat invasif serta mampu bermetastasis. Salah satu jenis kanker yang menyebabkan kematian dalam jumlah besar di Indonesia adalah kanker kepala dan leher. Kanker kepala dan leher adalah salah satu jenis kanker yang umum terjadi di dunia. Kanker kepala dan leher menyerang bibir, rongga mulut, langit-langit, faring dan laring (Patel \& Shah, 2005). Kanker ini umumnya disebabkan oleh kebiasaan merokok dan konsumsi alkohol yang berakibat pada terjadinya mutasi genetik. Mutasi genetik yang menyertai kanker kepala dan leher umumnya terjadi pada ekson 5-8 pada gen $p 53$, yang merupakan gen supressor tumor (Poltenen et al., 2010). Perkiraan jumlah kejadian kanker kepala dan leher secara global adalah sekitar 533.100 kasus per tahun (Parkin et al., 2005). Badan Registrasi Kanker Nasional di Indonesia, menempatkan kanker kepala dan leher pada urutan keempat dari sepuluh besar keganasan pada pria dan wanita (Wiliyanto, 2006). Data Nasional Institute for Clinical Excelence, (2004) di London, menyebutkan kanker kepala dan leher umumnya lebih sering dijumpai pada pria dibandingkan pada wanita. Hal ini disebabkan 
kebiasaan merokok dan konsumsi alkohol yang frekuensinya lebih sering dijumpai pada pria. Hal yang sejalan juga diungkapkan oleh National Cancer Registry Ireland (2011), yang menyebutkan bahwa jumlah penderita kanker kepala dan leher sejak tahun 1994-2009 lebih besar ditemukan pada laki-laki dibanding pada perempuan.

Seperti kasus kanker pada umumnya, keterlambatan penanganan menjadi salah satu penyebab besarnya kasus kematian pada kanker kepala dan leher. Umumnya, kanker terdeteksi setelah memasuki stadium yang tinggi. Hal tersebut disebabkan masih kurangnya kesadaran masyarakat untuk melakukan skrining kanker sejak dini. Stadium kanker menunjukkan tingkat keparahan kanker, menyangkut ukuran tumor (T), pembesaran nodus limfa terdekat $(\mathrm{N})$ dan metastasis kanker (M). Penentuan stadium kanker meliputi 3 parameter tersebut. Semakin besar tingkat keparahan kanker, makin tinggi stadium kanker (Deschler dan Day, 2008).

Selain stadium, hal yang juga penting diketahui dalam penanganan kanker adalah derajat diferensiasi sel. Derajat diferensiasi penting dalam menentukan jenis penanganan atau terapi yang akan diberikan. Derajat diferensiasi adalah penilaian mikroskopis terhadap sel kanker berdasarkan pembelahan sel, kemiripan bentuk sel ganas dengan sel asal homogenitas sel. Derajat diferensiasi penting untuk menentukan keganasan atau keagresifan dan sifat biologis sel kankernya (Ivan, 2007 dalam Kusuma, 2009; National Cancer Institute, 2009). Dengan demikian stadium, derajat diferensiasi penting diketahui untuk mengetahui metode penanganan kanker yang tepat.
Penelitian-penelitian terkait kanker kepala dan leher merupakan penelitian yang belum banyak dilakukan di Indonesia. Termasuk data penelitian epidemiologi terkait rasio laki-laki dan perempuan penderita kanker kepala dan leher masih terbatas jumlahnya. Penelitianpenelitian terdahulu oleh negara-negara barat, penting untuk menjadi dasar penelitian serupa untuk dilakukan di Indonesia.

Penelitian ini bertujuan untuk mengetahui epidemiologi kanker kepala dan leher terkait rasio penderita laki-laki dan perempuan dan melihat kaitan stadium dengan derajat diferensiasi pada setiap kasus kanker kepala dan leher yang diteliti, dengan mengambil tempat penelitian di Rumah sakit Kanker Dharmais Jakarta-Pusat Kanker Nasional.

\section{METODE}

Pengambilan data penelitian dilakukan di Rumah Sakit Kanker Dharmais Jakarta-Pusat Kanker Nasional pada Agustus 2014. Data yang diperoleh berupa data demografi pasien dan data klinis. Data demografi berupa data jenis kelamin dan usia pasien. Data klinis pasien berupa data stadium dan derajat diferensiasi tiap-tiap kasus kanker. Data yang diperoleh kemudian dianalisis secara deskriptif. Telaah pustaka dilakukan untuk memperkaya informasi, sekaligus menjadi data pendukung hasil penelitian yang diperoleh.

\section{HASIL}

Data yang diperoleh dari Rumah Sakit Kanker Dharmais Jakarta-Pusat Kanker Nasional berasal dari 36 pasien. Data demografi pasien disajikan pada Tabel 1.

Tabel 1. Data Demografi Pasien Kanker Kepala dan Leher

\begin{tabular}{|c|c|c|}
\hline Karakteristik Pasien & Jumlah (n) & Persentase (\%) \\
\hline \multicolumn{3}{|l|}{ Jenis kelamin } \\
\hline Pria & 19 & 52,77 \\
\hline Wanita & 17 & 47,22 \\
\hline \multicolumn{3}{|l|}{ Usia } \\
\hline$<60$ & 31 & 86,11 \\
\hline$\geq 60$ & 5 & 13,88 \\
\hline
\end{tabular}

Berdasarkan Tabel 1. diketahui bahwa jumlah pasien laki-laki penderita kanker kepala dan leher adalah 19, sedangkan pasien perempuan berjumlah 17 orang. Data distribusi 
stadium dan derajat diferensiasi penderita dari 36 pasien kanker kepala dan leher disajikan dalam Tabel 2.

Data yang disajikan dalam Tabel 2, kemudian dikelompokkan kembali berdasarkan stadium dan derajat diferensiasi ke dalam Tabel 3. Pengelompokan ini dimaksudkan untuk mempermudah analisa kaitan antara stadium dan derajat diferensiasi kanker kepala dan leher.

Tabel 2. Data Distribusi Stadium dan Derajat Diferensiasi Variabel Frekuensi

\begin{tabular}{ccc}
\cline { 2 - 3 } \multicolumn{1}{c}{} & Jumlah $(\mathrm{n})$ & Persentase $(\%)$ \\
\hline Stadium & & \\
\hline I & 2 & 5,55 \\
\hline II & 8 & 22,22 \\
\hline III & 9 & 25,00 \\
\hline Derajat Diferensiasi & 16 & 44,44 \\
\hline Baik & 1 & 2,77 \\
\hline Sedang & & \\
\hline Buruk & 16 & 44,44 \\
\hline Data tidak ditemukan & 4 & 11,11 \\
\hline
\end{tabular}

Tabel 3. Pengelompokan Data Stadium dan Derajat Diferensiasi

\begin{tabular}{|c|c|c|c|c|}
\hline \multirow[t]{2}{*}{ Stadium } & \multicolumn{3}{|c|}{ Derajat diferensiasi } & \multirow[t]{2}{*}{ Jumlah (n) } \\
\hline & Baik & Sedang & Buruk & \\
\hline \multirow{3}{*}{ I } & $\sqrt{ }$ & & & 2 \\
\hline & & $\sqrt{ }$ & & 0 \\
\hline & & & $\sqrt{ }$ & 0 \\
\hline \multirow[t]{3}{*}{ II } & $\sqrt{ }$ & & & 4 \\
\hline & & $\sqrt{ }$ & & 1 \\
\hline & & & $\sqrt{ }$ & 2 \\
\hline \multirow[t]{3}{*}{ III } & $\sqrt{ }$ & & & 4 \\
\hline & & $\sqrt{ }$ & & 2 \\
\hline & & & $\sqrt{ }$ & 0 \\
\hline \multirow[t]{3}{*}{ IV } & $\sqrt{ }$ & & & 6 \\
\hline & & $\sqrt{ }$ & & 1 \\
\hline & & & $\sqrt{ }$ & 7 \\
\hline Total & & & & 29 \\
\hline
\end{tabular}

\section{PEMBAHASAN}

Berdasarkan Tabel 1. Diketahi jumlah penderita kanker kepala dan leher lebih banyak dijumpai pada laki-laki dibanding perempuan, dengan persentase masing-masing untuk lakilaki dan perempuan $52,7 \%$ dan $47,2 \%$, meskipun jumlahnya tidak terpaut jauh. Jumlah yang tidak terpaut jauh tersebut dipengaruhi tingginya jumlah perokok pasif di Indonesia yang tentunya didominasi perempuan. Data perokok pasif di Indonesia dari tahun 2007-2011 terus meningkat. Tahun 2006 sebanyak 40,5\%, tahun 2009 78,1\% terpapar asap rokok diluar rumah, 68,8\% terpapar di dalam rumah dan tahun 2011 $78,4 \%$ terpapar di lingkungan luar rumah dan $85,4 \%$ terpapar di dalam rumah (Badan Penelitian dan Pengembangan Kesehatan, Kementerian Kesehatan Republik Indonesia, 2009). Tingginya kanker kepala dan leher pada laki-laki sejalan dengan penelitian-penelitian yang dilakukan sebelumnya di negara-negara 
lain, diluar Indonesia, yang menerangkan persentase laki-laki penderita kanker kepala dan leher lebih besar dibandingkan persentase perempuan. Tingginya persentase laki-laki dibanding perempuan disebabkan penggunaan alkohol dan rokok di Indonesia yang didominasi laki-laki. Data yang diperoleh dari Badan Penelitian dan Pengembangan Kesehatan, Kementrian Kesehatan Republik Indonesia (2009), diketahui pada tahun 2009 data remaja yang merupakan perokok aktif berjumlah $41 \%$ laki-laki dan 3,5\% perempuan, jumlah tersebut meningkat dari tahun 2006, dimana jumlah penderita laki-laki $24,5 \%$ dan perempuan $2,3 \%$. Peningkatan jumlah perokok remaja laki-laki cukup besar yaitu naik $26,5 \%$. Berdasarkan data tersebut, diketahui jumlah laki-laki perokok lebih besar dibanding perempuan, sehingga resiko menderita kanker kepala dan leher juga akan lebih besar dibanding dengan perempuan. Konsumsi alkohol oleh laki-laki 15 tahun keatas secara nasional di Indonesia menurut Suhardi (2011), masih tergolong relatif rendah. Meskipun demikian ada beberapa provinsi, kabupaten maupun kota yang memiliki prevalensi penggunaan alkohol yang cukup tinggi, seperti Sulawesi Utara, Sumatera Utara, Jawa Barat dan Jawa Timur. Tingkat konsumsi alkohol pada laki-laki di kota-kota tersebut telah menyamai prevalensi di beberapa negaranegara tetangga yang juga memiliki masalah dalam penanggulangan konsumsi alkohol yang tinggi. Meskipun konsumsi alkohol masih didominasi oleh laki-laki, tetapi khusus untuk wilayah Nusa Tenggara Timur dan Sulawesi Utara jumlah perempuan pengkonsumsi alkohol tergolong tinggi. Konsumsi alkohol yang tinggi pada laki-laki akan meningkatkan kemungkinan laki-laki untuk mengidap kanker kepala dan leher.

Alkohol dan rokok dapat menyebabkan mutasi genetik pada p53. p53 merupakan gen supressor tumor yang memainkan penting dalam menghambat terjadinya tumor. p53 mengkode Tumor-Protein 53 (TP53) yang keadaan normal berfungsi sebagai checkpoint dalam siklus sel sekaligus sebagai sensor kerusakan DNA di dalam sel, memperbaiki kerusakan DNA dan pengaturan apoptosis sel
(Leemans et al., 2011). Mutasi pada p53 menyebabkan struktur TP53 akan mengalami perubahan. Perubahan tersebut akan mempengaruhi fungsinya dalam menghambat terbentuknya tumor.

Seperti kasus kanker lainnya, penanggulangan kanker kepala dan leher akan semakin sulit seriring meningkatnya stadium kanker tersebut. Kurangnya kesadaran masyakarat akan pentingnya skrining kanker menyebabkan jumlah kanker kepala dan leher semakin meningkat. Kasus yang kerap dijumpai di masyarakat adalah keterlambatan pemeriksaan yang berimbas pada keterlambatan penanganan. Stadium kanker diketahui melalui pemeriksaan patologi anatomi, dengan memperhatikan ukuran dari tumor $(\mathrm{T})$, pembesaran nodus $(\mathrm{N})$ dan metastasis (M). Kanker yang telah mengalami metastasis akan lebih sulit untuk ditanggulangi jika dibanding kasus kanker yang belum bermetastasis.

Data klinis distribusi stadium dan derajat diferensiasi 36 pasien yang disajikan dalam Tabel 2. menerangkan, bahwa kasus kanker dengan stadium IV merupakan kasus yang paling banyak dijumpai dengan persentase $44,44 \%$, kemudian disusul dengan stadium III $(25,00 \%)$, stadium II $(22,22 \%)$ dan stadium I $(5,55 \%)$. Hal tersebut menunjukkan keterlambatan pemeriksaan yang dilakukan oleh pasien, disebabkan kurangnya pengetahuan dan kesadaran masyarakat untuk melakukan skrining kanker sejak dini. Sehingga umumnya kasus kanker terdeteksi setelah memasuki stadium lanjut. Stadium kanker menunjukkan tingkat keparahan kanker. Stadium penting untuk mengetahui harapan hidup pasien serta penanganan yang efektif. Tingkat keparahan berbanding lurus dengan stadium kanker. Semakin tinggi stadium, semakin parah kasus kanker dan semakin kecil harapan hidup (Kusuma, 2009). Pada penelitian ini terdapat $1(2,77 \%)$ kasus kanker yang data stadiumnya tidak diketahui sehingga tidak dapat dianalisa.

Selain data stadium, terdapat data terkait derajat diferensiasi yang juga penting untuk mengetahui jenis terapi yang akan diberikan kepada pasien. Jenis penanganan terkait terapi 
yang akan dilakukan terhadap pasien ditentukan setelah diagnosis kanker ditegakkan. Penanganan pasien kanker meliputi pembedahan, radiasi ataupun kemoterapi (Chamim, 2006). Data mengenai derajat diferensiasi juga diperoleh melalui pemeriksaan patologi anatomi melalui pemeriksaan mikroskopis. Derajat diferensiasi ini menunjukkan penilaian berdasarkan jumlah sel yang mengalami mitosis, kemiripan bentuk sel ganas dengan sel asal serta susunan homogenitas sel. Data ini penting dalam rangka menentukan sejauh mana kanker tersebut menginvasi tubuh penderita, atau tingkat keganasan dari kanker yang menyerang. Tingkat kemiripan bentuk sel ganas dengan sel asal dan jumlah mitosis menjadi fokus utama dalam penentuan derajat diferensiasi kanker. Sel dikatakan semakin ganas apabila perubahan bentuk menjadi tak terkendali dan kemiripan dengan sel normal semakin kecil (Ivan, 2007 dalam Kusuma, 2009; National Cancer Institute, 2009).

Stadium kanker dan derajat diferensiasi tidak selalu berbanding lurus atau tidak selalu berkorelasi satu sama lain. Hal tersebut dapat dilihat pada pengelompokan data stadium dan derajat diferensiasi pada Tabel 3. terdapat 6 kasus kanker stadium IV dengan diferensiasi baik, di sisi lain terdapat 2 kasus kanker stadium II dengan derajat diferensiasi buruk.

Pada penelitian ini terdapat $7(19,40 \%)$ kasus kanker kepala dan leher yang data derajat diferensiasinya tidak ditemukan sehingga tidak dapat dilakukan analisa lebih lanjut. Derajat diferensiasi yang baik menunjukkan bentuk sel kanker masih memiliki kemiripan dengan sel asal. Sedangkan kanker dengan derajat diferensiasi buruk menunjukkan bentuk sel kanker berbeda dengan sel asal. Untuk kanker yang tidak berdiferensiasi (undifferentiation) tergolong kanker anaplastik (National Cancer Institute, 2009).

Stadium dan derajat diferensiasi yang tidak selalu berjalan beriringan tersebut dipengaruhi oleh perbedaan imunitas pada masing-masing pasien. Faktor imunitas yang lemah menyebabkan tumor dapat terus tumbuh dan terhindar dari serangan sistem imun.
Tumor juga menghasilkan faktor yang menghambat migrasi makrofag, sehingga menekan dan memperlambat kerja sistem imun. Faktor imunitas yang pada akhirnya akan menentukan tumor terus tumbuh atau mati (Desen, 2013; Campbell et al., 2014). Tumor terjadi lebih sering terjadi pada orang dengan supresi sistem imun, dibanding orang normal. Sel tumor akan menghasilkan faktor imunosupresi seperti TGF- $\beta$ yang merupakan sitokin imunosupresi. Faktor imunosupresi menghambat diferensiasi sel-sel limfosit yang berperan dalam mekanisme destruksi tumor. Sehingga menurunkan kemungkinan sel-sel ganas untuk dikenali sel-sel limfosit (Mescher, 2009).

Pertahanan tubuh yang berperan dalam mematikan sel kanker dapat berupa pertahanan nonspesifik tubuh meliputi sel pembunuh alami (Natural Killer; NK) dan pertahanan spesifik yang diperantarai sel $\mathrm{T}$ (sel $\mathrm{T}$ sitotoksik). Sel $N K$ tidak bersifat fagositik, melainkan melumpuhkan target dengan menyerang membran sel target sehingga sel tersebut lisis. Sedangkan sel $\mathrm{T}$ sitotoksik membunuh sel target dengan menghasilkan protein perforin, yang fungsinya membentuk pori atau lubang pada membran sel target. Adanya pori pada sel target menyebabkan ion dan air terus menerus mengalir ke dalam sel target, sel-sel mengalami pembengkakan sehingga sel menjadi lisis (Mescher, 2009).

\section{KESIMPULAN}

Kanker kepala dan leher lebih banyak menyerang laki-laki dibanding perempuan dengan ratio penderita laki-laki $52,77 \%$ dan perempuan $47,22 \%$. Tingginya jumlah penderita laki-laki dipengaruhi faktor konsumsi alkohol dan rokok yang lebih banyak dijumpai pada laki-laki. Tidak terdapat korelasi antara stadium dengan derajat diferensiasi kanker kepala dan leher. Hal tersebut dipengaruhi oleh imunitas tiap-tiap orang yang berbeda.

\section{DAFTAR PUSTAKA}

Badan Penelitian dan Pengembangan Kesehatan, Kementrian Kesehatan Republik Indonesia. 2009. Data Rokok. 
http://www.litbang.depkes.go.id. Diakses pada 20 Juni 2014.

Campbell NA, Reece JB, Urry LA, Cain, ML, Wasserman SA, Minorsky PV, Jackson RB. 2014. Biology A Global Approach 10th Edition. England: Pearson Education Limited. hal 1126.

Chamim. 2006. Buku Acuan Nasional Onkologi Ginekologi. In: M Farid Aziz, Adrijojo, Abdul Bari Saifuddin, editors. Penentuan stadium klinik dan pembedahan kanker ginekologi. Jakarta: Yayasan Bina Pustaka Sarwono Prawirohardjo. hal 173-181.

Deschler DG, Day T. 2008. TNM Staging of Head and Neck Cancer adn Neck Dissection Classification. Alexandria: One Prince Street. hal 8.

Desen W. 2013. Onkologi Klinis. Jakarta: Fakultas Kedokteran Universitas Indonesia. hal 22-23.

Kusuma R, Miranti IP. 2009. Derajat Diferensiasi Histopatologik pada Kejadian Rekurensi Kanker Serviks. Semarang: Universitas Diponegoro Semarang.

Leemans CR, Braakhuis BJM, Brakenhoff RH. 2011. The Molecular Biology of Head and Neck Cancer. Natural Reviews Cancer. vol 11: 9-21.

Mescher A. 2009. Junqueira's Basic Histology Text and Atlas $12^{\text {th }}$ Edition. Indiana: McGraw-Hill Medical. pp 279-281.
National Cancer Institute. 2014. Tumor Grade. http://www.cancer.gov. Diakses pada 09 Juni 2014.

National Cancer Registry Ireland. 2011. Cancer of the Head and neck. Cancer Trends. Ireland: National Cancer Registry. pp 1.

National Institute for Clinical Excellence. 2004. Improving Outcome in Head and Neck Cancer. London: National Institute for Clinical Excellence. hal 10.

Parkin DM, Bray F, Ferlay J, Pisani P. 2005. Global Cancer Statistic, 2002. CA Cancer Journal Clinical. vol 55: 74-108.

Patel SG, Shah JP. 2005. TNM Staging of Cancer of The head and Neck: Striving for Unifornity Among Diversity. CA Cancer Journal Clin. vol 55(4): 242-258.

Poltenen JK, Helppi HM, Pääkkö P, Turpeenniemi-Hujanen,Vähäkangas KH. 2010. p53 in Head and Neck Cancer: Functional Consequences and Environmental Implications of TP53 Mutations. Head and Neck Oncology. vol 36(36): 1-10.

Suhardi. 2011. Preferensi Peminum Alkohol di Indonesias Menurut RISKESDAS 2007. Buletin Penelitian Kesehatan. vol 39(4): 154-164.

Wiliyanto O. 2006. Insiden Kanker Kepala dan Leher Berdasrkan Diagnosis Patologi Anatomi di Rumah Sakit Dr. Kariadi Semarang Periode 1 Januari 2001- 31 Desember 2005. Semarang: Fakultas Kedokteran Universitas Diponegoro. 